\title{
Legal Issues for Artificial Floating Islands
}

\author{
Maarten M. B. Flikkema' ${ }^{1}$, Fen-Yu (Vicky) Lin'², Pernille P. J. van der Plank ${ }^{3}$, Jos Koning ${ }^{1}$ \\ and Olaf Waals ${ }^{1 *}$ \\ ${ }^{1}$ MARIN, Wageningen, Netherlands, ${ }^{2}$ Blue21, Delft, Netherlands, ${ }^{3}$ Law, Economics and Governance, Utrecht University, \\ Utrecht, Netherlands
}

\section{OPEN ACCESS}

Edited by:

Ould El Moctar,

University of Duisburg-Essen,

Germany

Reviewed by:

Nikolaos Kourogenis,

University of Piraeus, Greece

Maarten Claringbould,

Leiden University, Netherlands

*Correspondence:

Olaf Waals

O.Waals@MARIN.n

Specialty section:

This article was submitted to Ocean Solutions,

a section of the journal

Frontiers in Marine Science

Received: 20 October 2020

Accepted: 13 July 2021

Published: 16 August 2021

Citation:

Flikkema MMB, Lin F-Y, van der Plank PPJ, Koning $J$ and Waals O (2021) Legal Issues for Artificial Floating Islands.

Front. Mar. Sci. 8:619462. doi: 10.3389/fmars.2021.619462
Developments of multi-use floating islands are accelerated by an increase in offshore activities and pressing needs to create extra space in coastal regions for the surging population. The Horizon 2020 EU funded research project Space@Sea developed a modular floating island concept for offshore multi-use applications and examined current legal issues and barriers concerning its development. In this paper a floating island is defined to be "an artificially created floater, or set of connected floaters, moored to the seabed of which the topside can be used for activities similar to activities on land". This paper aims to delve into governance issues like the assignment of authority on a multiuse floating island and the shift from regulating offshore living for working purposes to living purposes, as well as maritime law and property law (using the Netherlands as case study). Within the Exclusive Economic Zone (EEZ) a coastal state can establish, locate, and govern the floating island. For the high seas the International Maritime Organization (IMO) is the most probable organization to initiate a discussion on settlement of floating islands. For each activity on the floating island, limiting criteria regarding motions as well as safety rules and regulations need to be established. Industry and housing will have completely different requirements regarding safety which will not be possible to fit in a one size fits all regulation. This case study shows that current Dutch property law prohibit the division of ownership of buildings built on floating objects. They can only be owned together as one object. For urban expansion, future inhabitants will want to have the possibility to buy property, requiring an amendment of current property law. It is to be expected that other countries will have similar or additional governance challenges. The Space@Sea project has developed a technical solution for floating islands which have identified barriers for multi-use in the rules and regulations described in this paper. The paper urges the responsible institutions and stakeholders to take on their roles in overcoming these barriers.

Keywords: floating island, law, marine spatial planning, Space@Sea, regulatory framework and governance

\section{INTRODUCTION}

Most of the world's population lives in coastal areas where space has always been a commodity; available land has become increasingly limited and the soaring property prices urge cities to seek alternative solutions for urban expansion. A trend can be observed that more waterfront areas around the world resort to reclamation or repurpose large parts of existing urban space as the sea 
level rises due to global warming. There is thus an increasing interest to evaluate the merits and challenges for the use of ocean space. The European Commission has recognized this challenge in their Horizon 2020 research program on the topic of Blue Growth (European Union, 2012) and has called to turn seas and oceans into an asset for Europe.

Simultaneously offshore activities are expanding from the traditional oil and gas applications to renewable energy, aquafarming, transportation hubs, tourism, airports, and city extensions (Schultz-Zehden et al., 2018). These vary from relatively close to shore, to further offshore activities. Conventionally offshore activities are either done on a dedicated working platform, or on an artificially created island. Large multi-use floating solutions that synergize and contribute to efficient use of marine space have yet to be applied. Floating island concepts are the next step in existing offshore floating technology. Existing knowledge and technology can be used, however there are still technological barriers to be challenged. For example, the behavior of multi body interaction of many floaters together must be investigated.

One of the main benefits of a floating solution is the low ecological impact. Where gravity based artificial islands, created by landfill or poldering, heavily interfere with the environment, floating solutions, apart from potentially the anchoring, have no permanent impact on the environment. When designed properly, permanent shadow casting to the seabed could be avoided and new ecosystems could be created underneath the island. Floating islands can be used for temporary applications but should be robust enough to be a permanent solution.

In November 2017, 17 partners in the Space@Sea consortium Flikkema and Waals (2019) set out to provide sustainable and affordable workspace at sea by developing a standardized and cost-efficient modular island with low ecological impact. A generic floater was developed on which a wide variety of activities can be done, much like they would be done on land.

While the Space@Sea project developed a technical solution for floating islands, open issues remain which form a barrier for exploitation of the concept. Issues that need to be solved include technical issues regarding interconnecting of modules and optimization of structure designs and governance issues such as issues regarding building codes, governance, and regulations. Legal issues include maritime law, property law, maritime spatial planning, and classification rules for floating objects. Key challenge is in the fact that in creating artificial land (i.e., floating islands), current regulations impose much stricter maritime laws, rules, and regulations, as these are mainly based on oil and gas activities, limiting the application possibilities.

Space@Sea does not intend to solve these legal issues. Project partners, however, encountered some barriers which are worth summarizing as a first step to solving these issues. In this paper Space@Sea partners MARIN and Blue21 together with a property law specialist from Utrecht University will discuss the legal issues that need to be solved before multi-use floating islands can be created with similar applications as on shore.

In section "Definition of a Floating Island" of this paper a definition of floating islands is proposed as this is currently missing, subsequently section "Maritime Offshore and Shipping
Regulations" discusses the current maritime offshore and shipping regulations. In section "Urban and Maritime Spatial Planning" issues regarding urban and maritime spatial planning are discussed, section "Property Law in Maritime Aspects" discusses property law in relation to floating developments. In section "Discussion" a discussion of the regulatory and legal issues of floating islands is given and section "Conclusion and Recommendations" gives conclusions and recommendations.

\section{DEFINITION OF A FLOATING ISLAND}

When searching floating islands on the internet, most hits refer to a layer of aquatic plants, mud and peat ranging in thickness. These islands often are a natural phenomenon but can also be artificially created. In the context of this paper, however, a floating island is not plant based but artificially built structure, made of steel and/or concrete, on which human activities can take place.

A term often used for these kinds of islands are multi-use offshore platforms. This definition, however, is too limiting as a floating island can also exist with only one use or one main application on the island. Furthermore, this definition may also refer to a ship or (former) oil and gas platform fixed to the seabed.

In the current paper, a floating island refers to "an artificially created floater, or set of connected floaters, moored to the seabed of which the topside can be used for activities similar to activities on land." The floating island can either be moored far offshore or connected to shore as an urban extension. The floating island can withstand environmental conditions so that the motions of the deck are limited, resulting in operations and activities on top of the floater being not different than when these operations and activities would be done on land. Figure 1 gives an artist impression of a floating island for 2,000 inhabitants as being developed in Space@Sea where the application is housing and living.

\section{MARITIME OFFSHORE AND SHIPPING REGULATIONS}

The objective of "Regulations" is to control the way something is done or the way people behave to maintain a stable, consistent and predictable society. Regulations have been developed by various civilizations for millennia past and are still being developed and evolved today. Regulations can be effective if the defining authority has jurisdiction over the activities that take place, the people involved and if they can be, and are, enforced. Individual sovereign states define their own regulatory frameworks that apply for the people inside and enterprises operating inside their national jurisdiction.

National regulations do not extend into the deep ocean. Nonetheless, corporate activities and the presence of many people that are professionally involved with these activities do require a regulatory framework to ensure and protect the community and invested asset values (e.g., international shipping transport and trading, fishing, offshore energy production). The United Nations Convention on the Law of the Sea (UNCLOS) drafted 


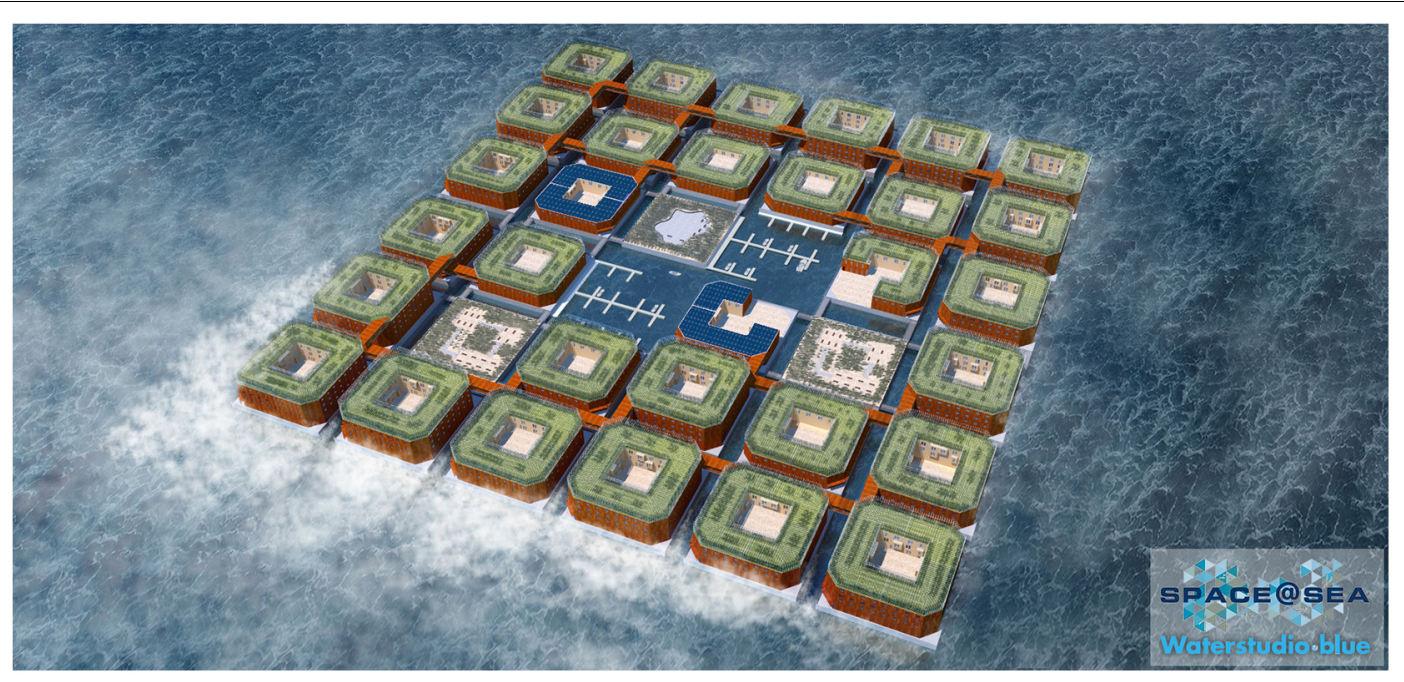

FIGURE 1 | Impression of a floating island. A floating island can be made of any material and have an arbitrary shape and floater type. The most obvious material is concrete, or steel and the shape of the top view is reckoned to be square or rectangle. For floater types semi-submersibles and barges make most sense. Any other materials, shapes or floater types, however, do not disregard the object to be called a floating island.

an outline regulatory framework in the "Convention on the High Seas" (1958). This is a framework to clarify jurisdiction and rights applicable to open waters and waters around nations. This convention is, however, not ratified by all countries so to this date there is not a worldwide accepted "law of the seas." This does not (yet) include the settlement of floating islands.

Under UNCLOS, 75\% of the world's surface which is the sea is divided according to:

- Territorial waters bordering coastal states. National legislation fully applies to 12 Nautical miles (Nm) out of the coast.

- Exclusive Economic Zones (EEZ). Nations have extended rights here and can place structures, but national legislation does not fully apply. This is up to $200 \mathrm{Nm}$ from the coastline.

- High Sea-Mare Liberum. No nation can claim ownership, all have equal rights for fishing and mining.

Strong concerns for sustainability with respect to fishing and mining call for a need of a regulatory framework to protect the world's oceans (Gjerde et al., 2013). At the same time, ships, their cargo, oil and gas plants and other offshore structures are risky and high value investments that operate in these oceans. Operating cost are high, requiring operators to balance risk and profitability against safety. Stakeholders have been searching for means to define rules to ensure their interests were looked after. Two types of such interests are reviewed in following paragraphs. These are:

- Financial risks related to private and corporate interests.

- Safety issues related to shipping which are more public interests.

\section{Rules for Financial (Private/Corporate) Interests}

The dominating "regulatory" system in international shipping is related to the interests of financial stakeholders. Financial risks are too high to be carried by single stakeholders. The shipping community developed a structure for insurances already in the period of the golden age. Mutual insurances were setup between shipping companies via Protection and Indemnity (P\&I) organizations. The P\&I organization would request compliance to minimal technical standards as laid out and inspected by their accepted Classification Society. This principle is still in place today. The "class rules for ships" that were defined and maintained by the first classification societies, evolved with the developments in shipping and offshore industry into what they are to this day. Rules are adjusted as needed following new designs, research studies, and experience with incidents. Specific class notations have been developed for different ship types, as well as oil and gas structures. Class rules include requirements to the design load cases, maximal probability of failure, design details, the materials used, the building process and many more. Class notation is an operational requirement even though it may not be formally mandatory since the risk of operation without insurance is unacceptable to (liable) stakeholders. Classification societies and the concept of class notation as such provide a dominant regulatory framework that exceeds national boundaries.

Many class bureaus exist nowadays. Examples are, Lloyds Register (LR), DetNorske Veritas/Germanische Lloyd (DNV/GL), Bureau Veritas (BV), American Bureaus of Shipping (ABS), Class NK, Korean Register, China Class Society (CCS). Class societies are rooted in specific nations but operate internationally. A large part of the world's class societies is linked through the International Association of Classification Societies (IACS) where overall concepts and standards are homogenized. 


\section{Rules Driven by Safety (Public) Interests}

The classic mission of the class societies was aimed at technical condition of the classed structure and in particular if it was technically fit to sail from the risk point of view for insurance. Safety and wellness considerations for crew, passengers and environment were not the explicit objective of original class regulations. After the first world war, and the sinking of the Titanic, the Safety of Life at Sea (SOLAS) convention was drafted, and the International Maritime Organization (IMO) was founded. The objective of IMO is to develop and maintain standards for safety of seafarers and environment. IMO is ratified in 2020 by 174 maritime nations. IMO itself has no jurisdiction, but membership obliges a nation to participate in the definition and maintenance of an international maritime regulatory framework, include that in their national legislation, and enforce that on the ships under their flag, and foreign ships calling their ports.

This has had following effects:

- The rules, guidelines and recommendations that are agreed in the IMO framework are implemented via individual IMO nations' legislation.

- IMO states accept only IMO flagged ships so deep-sea ships must comply to IMO rules to make port and join in the international shipping business.

Herewith, an international regulatory system is in place to address safety. The topics that are addressed inside the regulations can be grouped under 4 principal conventions. These are:

- SOLAS. Safety of Life at Sea convention, which is specifically focused onto the safety of the crew and passengers on board.

- MARPOL. Maritime Pollution convention, which specifically focused onto the impact of maritime operations onto the environment.

- STCW. Standard for Training, Certification and Watchkeeping. This addresses that all staff involved in tasks is properly trained, certified and that proper watch systems are in place.

- MLC. Maritime Labor Convention. This addresses explicitly the physical and mental wellbeing of the seafarers.

\section{Implementation}

Enforcement of the IMO conventions as rooted in national legislation falls under the responsibility of the flag state under which the vessel or floating structure is operated. This is typically handled by shipping inspectorate and port state control departments. Over past decades it has become challenging for national authorities to maintain the specialized resources to keep up with the rapid innovations in the maritime industry. Over recent years many authorities authorized class societies to verify compliance to IMO conventions on their behalf. Class rules can be more efficiently maintained than national legislation, they are globally recognized, and class notations include annual surveys that facilitate scheduled enforcement checking moments. The international association for the representation of the mutual interests of the inland shipping and their insurance and for keeping register of inland vessels in Europe (IVR) can play a similar role as IMO for the European inland waters and waterways for in-short developments of floating islands.

In effect the regulatory situation is that:

- Financial invested value, liability (and ultimate safety) is protected by rules set by Class as required for insurance coverage.

- IMO provides a framework of guidelines and mandatory rules that each vessel should comply to for public and environmental safety.

- IVR plays a similar role as IMO for inland waters and waterways.

- Flag states are responsible for the quality of the IMO rules, and enforcement of compliance by ships under their flag, and foreign ships calling their ports.

- Class societies include IMO standards in their class notations and are authorized to check for compliance. IMO compliance thus becomes a part of the class notation.

\section{Considerations Regarding Floating Islands}

Floating islands bring a new type of structure into the ocean. Their complexity is large, operational experience with similar structures is scarce, and confidence in design models and simulations is limited. New class rules for the structural design of these structures will have to be defined. Varieties of failure and incident scenarios will have to be evaluated before insurances will be ready to consider and cover risks and investors be willing to participate in the design, building, installation, and operation of floating islands.

Regulations for utilization and inhabiting floating islands will need to be developed as well. Some examples are regarding the relation to (inter)national authorities, maximum allowable motions for long term workers and urban inhabitants, provisions for non-work-related usage that may fall outside the scope of present IMO regulatory framework.

It is obvious that minimum requirements will be related to the intended location of the island and the activities to be performed on it.

\section{URBAN AND MARITIME SPATIAL PLANNING}

Land use zoning plans and maritime spatial planning are highly relevant regarding the introduction of floating development to urban or offshore environment. They are made to promote the efficient, safe, and sustainable use of water or land areas. Zoning plans are powerful spatial planning tools which include detailed rules on how a certain plot of land can be used, what type of buildings can be established and where, whereas maritime spatial planning is a means of fostering sustainable use of the seas while simultaneously allowing for private sector initiatives. Regarding new types of development such as floating islands, it is important 
to have an idea on the formation of urban spatial planning to understand the parties involved, in which stage and how can this type of development be considered. In this section, zoning plan for floating development in internal waters and maritime spatial planning in the territorial sea and Dutch EEZ are discussed.

\section{Land-Use Zoning Plans for Urban Development}

The control for spatial planning lies on a national-, sub-national or local level of a coastal State. The EU itself has no general control assigned within this field (Dallhammer et al., 2018). In the Netherlands, spatial planning decisions are made at the national, regional, and local levels. The national government, provinces and municipalities make a structural vision together, describing the spatial developments they expect for infrastructure and space, as well as how these developments will be directed or implemented. The municipalities for instance, further develop the vision into regional land-use zoning plans (Figure 2). Such plans set down where construction may take place, what may be built, the size of the structure and what it may be used for. The fixed components of a land-use plan include the rules and regulations for the area concerned and an illustration (planning map) that indicates and explains the various zones. When the interests of both national and provincial governments are at stake, they could come up with an integration plan.

\section{Maritime Spatial Planning}

When floating development will be situated in the territorial sea and the Dutch EEZ, it then becomes necessary to refer to maritime spatial planning. The competition for the use of maritime space has been ever-increasing and require nations to manage their waters more coherently. In 2014, the EU Directive 2014/89/EU on Maritime Spatial Planning was given to the coastal Member States of the European Union by the European Parliament and Council of the European Union. According to Lisbon Treaty Article 288, a directive shall be binding, as to the result to be achieved, upon each Member State to which it is addressed, but shall leave to the national authorities the choice of form and methods (Croner-i, 2020).

In response to the directive, the Netherlands updated the National Water Plan in 2015. The National Water Plan was firstly introduced in 2010 as a strategic framework based on the Dutch Spatial Planning Act, the Marine Strategy Framework Directive, and the Water Framework Directive. It replaced certain policy sections of the National Spatial Strategy and included the spatial plan for the North Sea. In 2014, North Sea 2050 Spatial Agenda had been published (Ministry of Infrastructure and Environment and Ministry, of Economic Affairs, 2014). In 2015, the Netherlands created the Policy Document on the North Sea 2016-2021, summarizing the long-term vision (2050) of the Netherlands and incorporated a maritime spatial plan (Ministerie van Infrastructuur en Waterstaat, 2015). In 2020, Het Akkoord voor de Noordzee (the North Sea Agreement) has also been drafted, indicating agreements between central government and stakeholders until 2030 with a view to the development of wind energy in the long term (Ministerie van Infrastructuur en Waterstaat, 2020). In short, the process of the development can be seen in Figure 3.

In the Policy Document on the North Sea 2016-2021, amongst all the policy choices laid down and detailed, various interests for marine activities were addressed, including shipping, defense, fishing, aquaculture and mariculture, underwater cultural heritage, tourism, and recreation, etc. In terms of floating, only "floating trans-shipment" was included as a potential use in the shipping sector. Nothing related to living on floating platforms was ever mentioned.

It has been indicated that industrial freedom and market forces prevailed during discussions on marine spatial planning in the Netherlands for years (De Vrees, 2019). With the new knowledge gained and in response to the urgent needs to create more space in a more sustainable manner, it might be high time that floating cities development be considered in the next round of revision of Maritime Spatial Plan. In the Policy Document, an assessment framework for activities in the North Sea has also been developed and outlined for central government to use for ascertaining whether activities at sea are permitted. The assessment framework is a policy regulation and obliges the competent authority to act in accordance with this framework when issuing permits (Ministerie van Infrastructuur en Waterstaat, 2015). It would be highly possible that floating cities would be evaluated under this framework if proposed to be included in the North Sea.

There are different approaches to address the needs of largescale sustainable floating city development. For the European Union, according to Lisbon Treaty Article 188, to exercise the Union's competences, the institutions shall adopt regulations, directives, decisions, recommendations, and opinions to the Member States. For floating island and floating city development to be brought into the regional agenda of spatial planning, different interest groups must work together, express their interests, and demonstrate the needs and urgency to regard floating city development as a serious option for future urbanization and as a better alternative to land reclamation. Such interests should be conveyed to the Council of the European Union and the European Parliament, who would then evaluate and make decisions upon. Depending on the sense of urgency and level of interests, in case the EU finds it necessary, it might address floating city development to its Member States in a certain format (e.g., regulation, directive, decision, recommendation or opinion) and have "living" or "urbanization" activities considered in maritime waters. It should, however, be noted that while promoting floating development is needed at all levels, not at least from international organizations like the EU, first and foremost attention should be paid to defining and circumscribing the concept/term of floating cities more clearly.

\section{PROPERTY LAW IN MARITIME ASPECTS}

Using water as an alternative to land raises several property law questions. How is a floating structure qualified: as a vessel, or in the same manner as a building on land? Is it possible to divide a 


\section{Spatial Planning for Urban Development}

- National Government

- Provinces

- Municipalities

- Municipalities

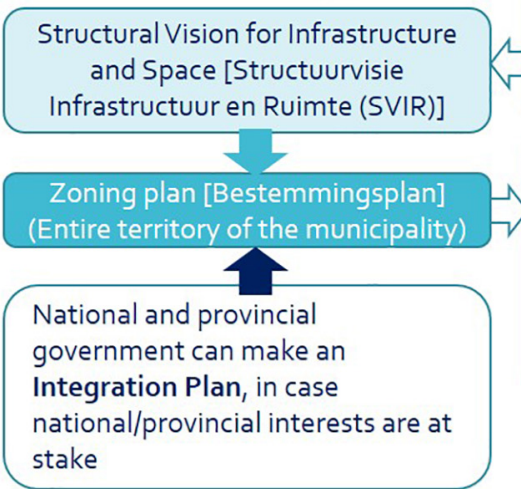

Published by the

Dutch Ministry of

Infrastructure and

Water Management

Private property

developers or

private individuals

buy/lease land

from the

government to

develop/build

accordingly

FIGURE 2 | The process of spatial planning for urban development come to being in the Netherlands. Land-use zoning plans allow for desired changes. In the face of increasing interests in floating development, the Municipality of Amsterdam, for instance, drafted a "Bestemmingsplan Drijvende Bouwwerken (Zoning Plan Floating Structures)," indicating a technical legal amendment to the Houseboat Clarification Regulations, which came into effect on January 1,2018 (Gemeente Amsterdam, 2018). In the document, the Municipality of Amsterdam has assigned 59 prevailing zoning areas for building on water within the city of Amsterdam. In 2019, the Municipality of Amsterdam announced "Vaststelling paraplubestemmingsplan Drijvende Bouwwerken" (The Adoption of the Umbrella Zoning Plan Floating Structures), expressing that an umbrella zoning plan with an updated framework has been introduced to assess applications for environmental permits for the building activities regarding floating structures. This was necessary to optimize the evaluation process (Gemeente Amsterdam, 2019). It can be observed that there have been ongoing efforts from the local government to consider development on water in its zoning plans.

\section{Maritime Spatial Planning for Activities on Water}

\section{- The European Parliament \\ - The Council of the European Union}

- EU Member States

E.g., the Netherlands
Directive 2014/89/EU Maritime Spatial Planning

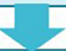

Urged to come up with Maritime

Spatial Plans (which should be

reviewed at least every 10 years)

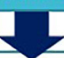

- North Sea 2050 Spatial Agenda (2014)

- Policy Document on the North Sea 2016-2021 (2015)

- The North Sea Agreement (2020)

Published by the Ministry of Infrastructure and Water

Management, the Ministry of Economic Affairs and Climate

Policy, and Ministry of Agriculture, Nature and Food Quality

FIGURE 3 | Maritime spatial planning for activities on water, giving the example of the Netherlands. One may be curious about the types of floating development have been included in these documents, and whether floating for living purpose was one of them. In the North Sea 2050 Spatial Agenda, floating constructions at sea for harvesting tidal and wave energy were included in the wind energy areas as a long-term energy solution since it is believed that combining energy generation technologies will offer financial, logistical, and spatial opportunities. What is also interesting to note is that a group of primary school students were asked by the Ministry of Infrastructure and Water Management to think about the future of the North Sea. One of the ideas that the students came up with was to introduce "floating hotels" to the North Sea, showing that our next generation seemed to consider living on water a possible activity in the North Sea in the future.

floating structure into apartment rights? Is it possible to create a limited real right on a floating platform or to encumber it with a security right, like a right of mortgage? Is it possible to divide the ownership of a floating platform so that if several buildings are built on a large floating platform, these buildings may belong to different owners?
The answers to these questions usually depend on whether a floating island is qualified as movable or immovable property. This is because the ownership of movable property cannot be encumbered with limited rights, like the right of superficies or an easement. In many legal systems, movable property cannot be divided into apartment rights 
either. ${ }^{1}$ This chapter uses the Netherlands as a case study example while it is reasonable to expect other countries will have similar or additional issues. The Netherlands has always been a frontrunner in challenging the water. Choosing the Netherlands as case study is therefore a good starting point.

In 2010, the Dutch Supreme Court concluded in the Woonark decision (Dutch Supreme Court, 2010) that under Dutch law a houseboat falls under the definition of a vessel and is therefore movable property. ${ }^{2}$ The definition of a vessel in the Dutch Civil Code is: "all things, other than aircraft, which, according to their construction, are destined to float and which float or have done so." 3 This definition is so broad that it could be argued, briefly put, that every floating construction qualifies as movable property. ${ }^{4}$ In this respect, the size of the floating construction does not matter, nor does the question of whether this is in any manner connected to the underlying land, i.e., to the water parcel. The Dutch Supreme Court held that the fact that a houseboat was connected to mooring posts by steel shackles and could not move at all, except for rising and falling with the water level for about half a meter, does not alter the fact that it must be qualified as a vessel (Van der Plank, 2011). This leads to the conclusion that a platform of, for example, $100 \mathrm{~m}$ by $100 \mathrm{~m}$, fastened with cables in the ground and on which there are several buildings, also still qualifies as a vessel, because it falls under that definition.

The fact that under current Dutch law anything that floats is qualified as a vessel (and is therefore movable), significantly limits the possibilities for floating building developments. Article 5:3 of the Dutch Civil Code provides that the owner of a thing is also the owner of its component parts (to the extent that the law does not provide otherwise). This provision includes an important property law principle: "the principle of unity". The Dutch Civil Code only includes exceptions to this principle of unity for immovable property, e.g., the accession by the land can be interrupted by means of the creation of a right of superficies. ${ }^{5}$ However, it is not possible to divide the ownership of movable property. This means that if five houses are built on one large floating platform, this only constitutes one thing and one ownership right under Dutch property law. Based on the principle of unity, it is not possible to transfer the ownership of each of the five houses separately. This explains why, so far, floating developments in the Netherlands have

\footnotetext{
${ }^{1}$ In Dutch law, this is shown in Article 5:106 (1) of the Dutch Civil Code. There are, however, many examples of legal systems in which it is possible to divide a vessel into apartment rights. See, for example, Article 8:197 of the Civil Code of Aruba, which provides: "The only rights in rem of which a seagoing vessel listed in the register can be subject, are the ownership, apartment rights and time-shared apartment rights, the mortgage, the usufruct and the preferential rights referred to in Article 211 and Article 217, first paragraph, part b."

${ }^{2}$ In this contribution, Dutch law will be used to illustrate the property law problems that may play a part in floating development.

${ }^{3}$ See Article 8:1 of the Dutch Civil Code.

${ }^{4}$ This was confirmed by the Dutch Supreme Court in its Marina judgment, see Dutch Supreme Court 9 March 2012, ECLI:NL:HR:2012:BV8198.

${ }^{5}$ See Article 5:101 of the Dutch Civil Code, which provides: The right of superficies is a right in rem to own or to acquire buildings, works or vegetation in, on or above an immovable thing owned by another.
}

been limited to single houses: one floating platform, with one house on it.

With a view to the future, a separate regulation for floating buildings is required. ${ }^{6}$ At present, much work is being done on a bill to create a separate legal framework in the Dutch Civil Code for floating buildings and structures. The first part of the legislation has been published in 2021, see Ploeger and van der Plank (2021) The starting point in this respect is that floating developments will no longer be equated with vessels, but will be qualified as immovable property, so that the regulations for buildings and structures on land can be followed. ${ }^{7}$ The drafting of this bill, however, creates some other serious challenges. Immovable property, for example, is in principle acceded by the ownership of the land, but this is by no means always a desirable starting point for floating developments. It is not hard to imagine that the Municipality of Amsterdam would not be very keen on becoming the owner of every houseboat in the Amsterdam canals all at once, based on a possible change in the law. For this reason, it is debatable whether it is desirable that floating objects are acceded by the land underneath these objects in the same manner as buildings on land. Another question is where the dividing line should be drawn between a movable vessel and an immovable floating structure. In short: there are still some issues to be resolved before a suitable regulation for floating buildings is a fact.

Dutch law has been used above to illustrate the problems that may arise if there is a wish to start building on floating objects on a large scale. However, these problems regarding the legal qualification of floating objects are not exclusive to the Netherlands. Building on floating objects is still in its infancy. There is currently no legal system in the world that has embedded larger-scale floating development in the law. All current construction legislation is related to building on land. This means that regulations related to building on water are still a blank canvas, but also that every country that wishes to start building on water will have to look for a way to suitably embed this in the existing legal system. The draft Dutch bill may be an inspiration.

\section{DISCUSSION}

The previous sections have addressed several issues which need to be clarified and/or developed before multi-use floating islands

\footnotetext{
${ }^{6}$ In the KNB (Royal Dutch Association of Civil-law Notaries) preliminary advice "Boek 5 BW van de toekomst" (Book 5 of the Dutch Civil Code of the future), The Hague: SDU 2016, a first step was made to create a separate legal framework for floating objects. The essence of this proposal was the possibility to register a floating structure using a notarial deed and registration thereof as immovable property. In this proposal the berth also belonged to the immovable property. See section "Property Law in Maritime Aspects" "drijvende opstallen" (floating structures) by A.J. Mes, H.D. Ploeger and B.A.M. Jansen.

${ }^{7}$ The purpose of the draft bill is to make large-scale floating building possible. If floating development really starts to boom and the platforms become larger and larger, it raises the question of whether at some point floating platforms should be equated to land. See more about this subject in: P.J. van der Plank, "De introductie van drijvende percelen" (The introduction of floating property), WPNR 2015/7071 and P.J. van der Plank, "Een eerste stap naar drijvend wonen op grotere schaal" (A first step toward large-scale floating houses, Maandblad voor Vermogensrecht (Property Law Monthly), 2016/0708.
} 
can become a reality, specifically concerning habitation of the floating island. This chapter discusses possible directions for solutions of the three main issues which have been identified above:

- Who has authority to govern on the floating island?

- Activities shifting from professional purpose to leisure and living purposes

- Property law

The primary objective of rules, regulations and laws should be to assure a safe environment and protect owners and residents.

\section{Authority to Govern on the Island}

The issue of who has authority on the water was discussed in section "Maritime Offshore and Shipping Regulations" with the EEZ and high seas being areas for which the authority is unclear or undefined. As for ships, floating islands may be assigned a flag state to which it is registered, assigning the authority on the island to that flag state. For security and political reasons, it is undesirable that foreign states create large floating islands in the EEZ of other states. Maritime laws should be adjusted to specifically limit the forming of floating islands under the flag of another state in the EEZ of any state. The state to which the EEZ belongs is the only flag state allowed in this region for floating islands.

IMO will need to agree on flag state on the high seas and specify which rules apply to the settlement of a floating island in these areas of the seas. Although flag states will have (to define) specific rules and regulations for floating islands focussing for example on environmental protection. It is undesirable that a floating island with a flag state with not so strict rules regarding pollution are placed just outside the EEZ of a state with strict pollution rules. As for shipping, general rules are defined regarding pollution on the high seas.

Although the flag state has an influence on the rules, regulations and laws on the floating island, it does not specifically mean that the state needs to take a (ownership) role in the development. Although extension of land for instance recently in the Netherlands for the Maasvlakte 2 often is initiated by the state then also owning the newly created land. This could happen for floating islands too, developments will need to show how this evolves. For multi-use floating islands the role for the state is more evident as different stakeholders need to be brought together. For single use floating islands probably, a commercial party could be the owner of the floating island as is the case for other offshore structures such as oil and gas platforms. In both cases it is not said that the government must be the owner of the floating island, new partnership forms can arise to facilitate this.

\section{Type of Activities}

As discussed in section "Urban and Maritime Spatial Planning," maritime activities to date have mainly been professional activities as well as leisure activities for yachting and for cruise vessels. Regulations for large maritime structures assume that these are professional structures where work is being done.
From one side this means that strict safety regulations apply also regarding operability, limiting the motions of the structure. On the other hand, this also assumes that the people working are professionals who have chosen to go to sea and that they can cope with more severe motions than people living and working on land. The interior of ships for instance are designed such that it can cope with rolling and pitching of the vessel, meaning that all furniture is sea fastened and tables have a raised edge preventing stuff to fall off. As floating islands should be more like land-based operations, the motions of the floating islands should be limited such that furniture does not have to be sea fastened.

The type of activities on the floating island will predominantly dictate the limiting ship motions and the limiting environmental conditions for the operations on the island. For habitation which should be like habitation on land, this means only very minor motions are allowed. With the layout of the floating island this can be tuned as modules in the middle of the island will have less motions than those at the sides. Therefore, per application limiting criteria for motions need to be defined which in turn need to be input for the urban planning of the floating island.

\section{Property Law}

Property law is mainly an issue for habitation of floating islands, but also for multi-use industrial applications. If the multi-use floating island is a modular island with only one application and one owner per module, property law should not be an issue as the floater and all structures on top are property of the single application owner. However, if the floater is large and multiple activities are done on the floater, ownership of the structure on the floater is an issue, as it is for houses on the floaters. A point of attention here is that the land underneath the floating island may differ from the ownership than the island or at least the (Dutch) property law has to be amended in that respect.

A possible solution for property law would be to adapt the definition of immovable objects as objects that are not meant to move. Although a modular floating island is meant to be flexible and modules can be relocated, primarily the island is not meant to move as a whole or as individual modules. If individual modules are going to be moved, it should be agreed that this can only be done if all owners of property on the modules agree and that the flag state of the module does not change. In case a module needs to change flag state as it will join a floating island of another flag state, this can only be done if there is only one owner of property. This means that the owner of the floater needs to buy back the property on the floater. This is not much unlike expropriation which is done on land if a municipality want to assign another application to the land.

\section{CONCLUSION AND RECOMMENDATIONS}

Based on the review of the legal issues for floating islands in this paper, the following conclusions can be drawn: 
- Within the current framework of rules, regulations and laws a floating modular structure supporting multiple activities is already possible, although some rules, regulations and laws prevent this being an attractive option for some applications.

- Single use floating islands are possible and likely to take to the seas in the coming decade as steppingstone for multi-use modular floating islands.

- The Horizon 2020 Space@Sea project has provided a technical solution for modular floating islands which can be the basis for the forming of rules, regulations and laws. The project has defined operational limits for certain applications, to be used as starting point of the discussions.

- Property law prohibits ownership of property of structures on a floating island as a floating island is seen as a movable object.

- Floating islands or floating cities are to be brought into the agenda of both urban and maritime spatial planning as a further step toward realization; however, first and foremost attention should be paid to defining and circumscribing the concept/term of floating cities or floating cities more clearly.

The discussion in section "Discussion" leads to the following recommendations regarding legal issues for floating islands:

- A clear definition of floating islands needs to be generated based on which rules, regulations and laws can be made. The authors of this paper recommend using: "an artificially created floater, or set of connected floaters, moored to the seabed of which the topside can be used for activities similar to activities on land."

- Floating islands should receive a flag state classification to appoint to which country the floating island belong and therefore which laws apply on the island.

- Restrictions regarding settlement of floating islands need to be in place in the EEZ for floating islands with a flag state other than the state to which the EEZ belongs.

\section{REFERENCES}

Croner-i. (2020). Article 288 | Croner-i Tax and Accounting. Available online at: https://library.croneri.co.uk/cch_uk/btl/euro-it-treaty-tfeu-art-288 (accessed Jun 23, 2020).

Dallhammer, E., Gaugitsch, R., Neugebauer, W., and Böhme, K. (2018). Spatial Planning and Governance Within EU Policies and Legislation and Their Relevance to the New Urban Agenda. Eur. Union. Luxembourg: Eur. Union.

De Vrees, L. (2019). Adaptive marine spatial planning in the Netherlands sector of the North Sea. Mar. Policy 132, 103418. doi: 10.1016/j.marpol.2019. 01.007

Dutch Supreme Court (2010). ECLI:NL:HR:2010:BK9136 (Houseboat Judgment). Hague: Dutch Supreme Court.

European Union (2012). Consolidated Version of the Treaty on the Functioning of the European Union Part Six - Institutional and Financial Provisions. Title I - Institutional Provisions. Chapter 2 - Legal Acts of the Union, Adoption Procedures and Other Provisions Section 1 - The legal Acts of the Union Article 288 (ex Article 249 TEC), Official Journal of the European Union, Brussels. Available online at: https://eur-lex.europa.eu/legal-content/EN/TXT/ ?uri=celex $\% 3 \mathrm{~A} 12012 \mathrm{E} 288$
- For each activity on floating islands limiting criteria regarding motions need to be defined which in turn should form the basis for urban planning of a floating island as well as the applicable rules and regulations.

- Property law for ownership of property and structures on the floating islands need to be adapted such that people can own houses and multiple companies can own a structure on the same floater. As these are national laws, this needs to be arranged for each flag state individually.

\section{AUTHOR'S NOTE}

Space@Sea was a partnership between the following partners: MARIN, DeltaSync, DST, NEMOS, TU Delft, MOCEAN, TU Hamburg Harburg, Bluewater, University Rostock, GICON, Wageningen University Research, University Duisburg Essen, TU Graz, Waterstudio, Icepronav, VAL FoU, and DEME.

\section{AUTHOR CONTRIBUTIONS}

MF contributed to the definition of a floating island and the discussion. F-YL contributed to the section on urban and maritime spatial planning. PP contributed to the text on property law in maritime aspects. JK and $\mathrm{OW}$ contributed to the maritime offshore and shipping regulations chapter. All authors together contributed to the integration of the texts.

\section{FUNDING}

This project has received funding from the European Union's Horizon 2020 Research and Innovation Program under grant agreement no. 774253 .

Flikkema, M., and Waals, O. (2019). Space@Sea the floating solution. Front. Mar. Sci. 6:553. doi: 10.3389/fmars.2019.00553

Gemeente Amsterdam (2018). Bestemmingsplan Drijvende Bouwwerken. Amsterdam: Government of Amsterdam.

Gemeente Amsterdam (2019). Vaststelling Paraplubestemmingsplan Drijvende Bouwwerken, Gemeente Amsterdam. Amsterdam: Government of Amsterdam.

Gjerde, K. M., Currie, D., Wowk, K., and Sack, K. (2013). Ocean in peril: reforming the management of global ocean living resources in areas beyond national jurisdiction. Mar. Pollut. Bull. 74, 540-551. doi: 10.1016/j.marpolbul.2013.07.037

Ministerie van Infrastructuur en Waterstaat (2015). Policy Document on The North Sea 2016-2021 (Printversie)-Policy Note - Government.nl. Available online at: https://www.government.nl/documents/policy-notes/2015/12/15/policydocument-on-the-north-sea-2016-2021-printversie (accessed Jul 8, 2020).

Ministerie van Infrastructuur en Waterstaat (2020). Het Akkoord Voor de Noordzee-Rapport-Rijksoverheid.nl. Available online at: https: //www.rijksoverheid.nl/documenten/rapporten/2020/06/19/bijlage-oflrapport-het-akkoord-voor-de-noordzee (accessed Jul 15, 2020).

Ministry of Infrastructure and Environment and Ministry, of Economic Affairs (2014). North Sea 2050 Spatial Agenda. Hague: Ministry of Infrastructure and Environment. 
Ploeger, H. D., and van der Plank, P. J. (2021). 'Wetsvoorstel Drijvende Opstallen: Een Juridisch Fundament Voor Bouwen op Water Deel I: Onroerende Drijvende Opstallen', Weekblad Voor Privaatrecht, Notariaat en Registratie, 2021/7319. Den Haag: sdu.

Schultz-Zehden, A., Lukic, I., Onwona Ansong, J., Altvater, S., Bamlett, R., Barbanti, A., et al. (2018). Ocean Multi-Use Action 253 Plan. Edinburg: MUSES Project.

Van der Plank, P. J. (2011). 'Havenkranen onroerend? Over Het Verschil Tussen Rijden en Drijven. N.a.v. Hoge Raad 24 december 2010, LJN BO3644', NTBR 2011, 27:202. Alphen aan den Rijn: Wolters Kluwer.

Author Disclaimer: The opinions in this document reflect only the author's view and in no way reflect the European Commission's opinions. The European Commission is not responsible for any use that may be made of the information it contains.

Conflict of Interest: F-YL was employed by the company Blue21.
The remaining authors declare that the research was conducted in the absence of any commercial or financial relationships that could be construed as a potential conflict of interest.

Publisher's Note: All claims expressed in this article are solely those of the authors and do not necessarily represent those of their affiliated organizations, or those of the publisher, the editors and the reviewers. Any product that may be evaluated in this article, or claim that may be made by its manufacturer, is not guaranteed or endorsed by the publisher.

Copyright (c) 2021 Flikkema, Lin, van der Plank, Koning and Waals. This is an open-access article distributed under the terms of the Creative Commons Attribution License (CC BY). The use, distribution or reproduction in other forums is permitted, provided the original author(s) and the copyright owner(s) are credited and that the original publication in this journal is cited, in accordance with accepted academic practice. No use, distribution or reproduction is permitted which does not comply with these terms. 